\title{
Retraction Note to: Neonatal Umbilical Myiasis with Sepsis
}

\author{
Y. C. Beeregowda $\cdot$ B. Kiran • N. Yellappa Gowda
}

Published online: 15 May 2012

(C) Dr. K C Chaudhuri Foundation 2012

Retraction to: Indian J Pediatr (2010) 77:1443-1445

DOI:10.1007/s12098-010-0236-5

This article was retracted due to copyright problems.

The online version of the original article can be found at http://dx.doi. org. 10.1007/s12098-010-0236-5.

Y. C. Beeregowda $(\bowtie) \cdot$ B. Kiran $\cdot$ N. Y. Gowda

Department of Paediatrics, Sri Devaraj URS Medical College,

Tamaka,

Kolar 563101 Karnataka, India

e-mail: rljhunit8@gmail.com 